The diagnosis of NMS is often problematic, because of both non-specific diagnostic criteria and the possibility of coexistent pathology.

Febrile illness in patients receiving neuroleptics is more common than NMS; however, the mortality rate from NMS is about $20 \%$ (Pope et al, 1986). A cautious course of action would be to consider the immediate withdrawal of neuroleptics in a patient with a fever from any cause, while further urgent diagnostic evaluation is undertaken.

Cohen, O., Leibovici, L., Mor, F., et al (1991) Significance of elevated levels of serum creatine phosphokinase in febrile diseases: a prospective study. Reviews of Infectious Diseases, 13, 237-242.

MARCUS, E. L., RUdensKy, B. \& SONNenblick, M. (1992) Oocult elevation of CPK as a manifestation of rhabdomyolysis in the elderly. Journal of the American Geriatrics Society, 40, 454-456.

Pope, H. G. Jr, KeCK, P. E. Jr \& McElroy, S. L. (1986) Frequency and presentation of neuroleptic malignant syndrome in a large psychiatric hospital. American Journal of Psychiatry, 143, 1227-1233.

Renwick, D. S., Chandraker, A. \& Bannister, P. (1992) Missed neuroleptic malignant syndrome. British Medical Journal, 304, 831-832.

Department of Geriatrics

Sarah Herzog Memorial Hospital

POB 35300

Jerusalem 91351

Israel

\section{Self videotaping during psychosis}

SIR: Psychiatrists sometimes have to use unusual sources of information when assessing a patient. I wish to report a case where an objective account of a patient's illness was unknowingly provided by serial videotape recordings in the absence of other informants.

Case report. A 27-year-old divorced man was brought to hospital by his father as an emergency. He was floridly psychotic and described auditory and visual hallucinations with delusions of persecution and reference. He had no insight, was guarded and suspicious, and refused to give any further details.

Obtaining background information was difficult. His parents were divorced and lived away, having had no close contact with the patient for a year. He had lived as a recluse, with no close friends or acquaintances, and he was not registered with a general practitioner. There was no evidence of drug or alcohol abuse, and a physical examination and urgent investigations were normal. Despite an incomplete assessment, treatment with oral chlorpromazine was begun immediately, because of his obvious distress.

As he improved, the patient told us of his interest in audiovisual equipment and that he had purchased a video camera and had installed a small sound studio in his house. Over the previous year, he had begun to believe that he was being interfered with by witches, who were causing his "brain and body to physically change" through witchcraft. Pleas to the police had been unsuccessful. To provide evidence of this interference, he had deliberately videotaped himself several times over the year.

The patient gave us his consent to view these tapes. Each lasts a few minutes and consists of the patient talking directly to the camera. He gives the date and then describes his various experiences in detail. On several occasions he is angry and distressed, and clearly describes third-person auditory hallucinations, delusions of reference, and visual hallucinations. Throughout his illness and on recovery, the patient did not regain any insight, and believed his tapes to be conclusive proof of the validity of his beliefs. He made an uneventful recovery and was discharged.

An autobiographical account of a psychotic breakdown written after recovery has been described before (Hunter \& MacAlpine, 1956).

The memoirs of Shreber, describing his paranoid psychosis while he was the presiding judge at the Dresden Appeal Court, provided the basis for Freud's psychoanalytical theories of paranoia (Strachey, 1958).

Film has been used in psychiatry since the 1930 s to illustrate the clinical features of disorders, to present specific therapies, and as a treatment itself as part of group therapy (Pilkington, 1984). More recently the use of audiovisual material has increased and experience of it is important for all psychiatrists. Its value in improving interview techniques has been established (Maguire et al, 1986). Patients are sometimes videotaped before recovery for later case presentations and study, but consent is often difficult to obtain, particularly from an acutely ill or paranoid patient.

The use of videotape to record one's own illness has not been reported previously. Written accounts necessarily suffer from being subjective, whereas this patient's account is objective, recorded at the time of the actual perceptions and while unwell. As technology increases and the availability of video cameras becomes more widespread, this type of self-documentation may increase.

My thanks to Dr E. H. Richards for his kind permission to publish this case report.

Hunter, R. \& MACAlPINE, I. (1956) 300 Years of Psychiatry, pp. 154-157. London: Oxford University Press.

Maguire, P., Fairburn, S. \& Fletcher, C. (1986) Consultation skills of young doctors. British Medical Journal, 292, 1573-1576. 
Pilkington P. I., (1984) The use of film in psychiatry. Bulletin of the Royal College of Psychiatrists, 8, 216-217.

STrachey, J. (1958) The Complete Psychological Works of Sigmund Freud. London: Hogarth Press.

Anthony J. Elliotr

WRI Newtown Branch

Newtown Road

Worcester WR5 1JG

\section{CORRIGENDA}

Journal, February 1992, 160, 191-202. CrossNational Collaborative Panic Study. Footnote 1 to Table 2 should read as follows: 1. Scale range 1-10, with higher score indicating less illness. The order of the bars in each group of three in Fig. 1, reading from left to right, is as follows: alprazolam, imipramine, placebo.

\section{A HUNDRED YEARS AGO}

\section{The increase of female inebriety and its remedy}

The causes of inebriety being both physical and mental, the combination of medicines with hygienic measures, intellectual, moral, and elevating influences, with absorbing occupation, largely muscular, are all called for. The plan of punishing female drunkards having utterly failed, though many of these have undergone hundreds of doses of this "cure," it is manifest that a new departure must be made. Hitherto, we have treated habitual drunkards as wilful criminal offenders. Let trial be made of the method of treating them as diseased individuals, in a hospital instead of in a prison. The most unremitting care of magistrates, constables, and prison cells having proved futile, if the Legislature, as there are strong indications will be the case, will hand these offenders over to the medical profession, with adequate appliances and powers of seclusion, we have little doubt that a large proportion of these hitherto uncured women will be relieved of their malady, and will become peaceful, industrious, lawabiding citizens. The experiment will be a grand one, fraught with important issues alike to the criminal and non-criminal victims, the profession, and the community at large. Ample provision should also be made for a similar compulsory therapeutic procedure in the case of all classes of confirmed inebriates.

\section{Reference}

British Medical Journal, 1 October, 1892, 751-752.

Researched by Henry Rollin, Emeritus Consultant Psychiatrist, Horton Hospital, Epsom, Surrey 